\title{
REVIEW
}

\section{HPV infections and tonsillar carcinoma}

\section{S Syriänen}

J Clin Pathol 2004;57:449-455. doi: 10.1136/icp.2003.008656

Since human papillomavirus (HPV) was first linked to laryngeal/oral carcinomas in 1983, several studies have confirmed its causal role in a subgroup of upper aerodigestive tract tumours. Of the non-genital cancers, tonsillar carcinomas (TCs) have the strongest association with HPV. By the end of 2002, 432 TCs had been analysed for HPV DNA. Overall detection rate was $51 \%$, with HPV16 being the most prevalent (84\%). The original proposal that HPV-33 would be the most frequent HPV in TCs has not been confirmed, being present in only $4.6 \%$ of cases. HPV copy numbers are similar to those found in genital carcinomas (10-300 copies/cell), although HPV is mainly episomal in TC. The importance of this observation is unclear, although a role for subepithelial proliferative lymphatic tissue has been speculated. Patients with HPV-16 positive tumours have better overall and disease specific survival than HPV negative patients. They are also younger and the association with conventional risk factorssmoking and drinking - is less significant than in HPV negative patients. Thus, recent data suggest a distinct pattern for HPV-16 positive TCs.

\footnotetext{
Correspondence to: Professor S Syriänen, Department of Oral Pathology, Institute of Dentistry, Faculty of Medicine, University of Turku, Lemminkäisenkatu 2, FIN-20520 Turku, Finland; stina.syrjanen@utu.fi

Accepted for publication 29 January 2004
}

W aldeyer's ring consists of submucosal and subepithelial lymphatic tissues localised in the region of the pharynx. The distinct structures of Waldeyer's ring comprise the tubal, pharyngeal, palatine, and lingual tonsils (fig 1). The pharyngeal tonsils, also know as adenoids, consist of a single pyramidal mass of lymphatic tissue, located at the posterior superior nasopharynx. The surface is folded with no true crypts. ${ }^{1}$ Palatine tonsils, frequently referred to as the tonsils, are bilateral structures situated in the tonsillar beds. Palatine tonsils consist of 10-30 crypts, lined by the surface epithelium. The lingual tonsils are an aggregation of lymphatic tissue located in the lamina propria of the root of the tongue. There is only one crypt for each nodule in the lingual tonsils. ${ }^{1}$

Pharyngeal, palatine, and lingual tonsils form part of the secondary immune system. They are exposed to ingested or inspired antigens that pass through the epithelial layers. The immunological structure is divided into four compartments: reticular crypt epithelium, extrafollicular area, mantel zone of the lymphoid follicle, and the germinal centre of the lymphoid follicles. The epithelium overlying the lymphatic tissues in the tonsil crypts is of the squamous cell type. As usual, antigens are presented to $\mathrm{T}$ helper cells, thereby inducing a $B$ cell response in the germinal centre, which results in antibody production. Secretory IgA is the main antibody produced in the tonsils.

Several microbial organisms can infect the tonsils, the best known agents being EpsteinBarr virus, adenoviruses, influenza $\mathrm{A}$ and $\mathrm{B}$ viruses, herpes simplex virus, respiratory syncytial virus, and parainfluenza virus. ${ }^{2}$ During the past 10 years, increasing evidence has suggested that human papillomaviruses (HPVs) can also infect the tonsillar epithelium. ${ }^{3} 4$ Similar to other mucosal sites, HPV infections have been associated with malignant transformation in this anatomical region. $^{3-9}$ However, there is much confusion in the literature regarding HPV infections in head and neck cancers. Head and neck cancer includes cancer of the lip, the oral cavity, the nose and sinuses (sinonasal cancer), the nasopharynx, the oropharynx, the hypopharynx, the larynx, the oesophagus, and the salivary glands, in addition to the soft tissues of the neck and ear (fig 1). Thus, the detection rates of HPV reported in head and neck cancer do not provide us with a detailed view on the association with HPV in the distinct entities, unless their detailed anatomical locations are given.

\section{"There is much confusion in the literature regarding human papillomavirus infections in head and neck cancers"}

When studying the literature, even nonepithelial tumours, such as lymphomas and sarcomas, are often included among head and neck cancers in these reports. Consequently, assessment of the real detection rates of HPV DNA in tonsillar carcinomas is laborious, necessitating the scrutiny of the tables of all individual studies reporting on both head and neck cancers and cancers of the upper aerodigestive tract. In this review, these reports will be summarised by grouping the lesions according to their accurate anatomical location (whenever possible), to give the reader a more organised view on these complex data.

ORAL AND PHARYNGEAL CARCINOMAS Oral and pharyngeal carcinomas are classified topographically according to their site of origin into the following categories: lip, floor of the mouth, tongue, buccal mucosa, retromolar trigone, hard palate, base of the tongue, tonsillar area (including the anterior and posterior

Abbreviations: $\mathrm{Cl}$, confidence interval; $\mathrm{HPV}$, human papillomavirus; ICD, international classification of diseases; ORF, open reading frame; SCC, squamous cell carcinoma 


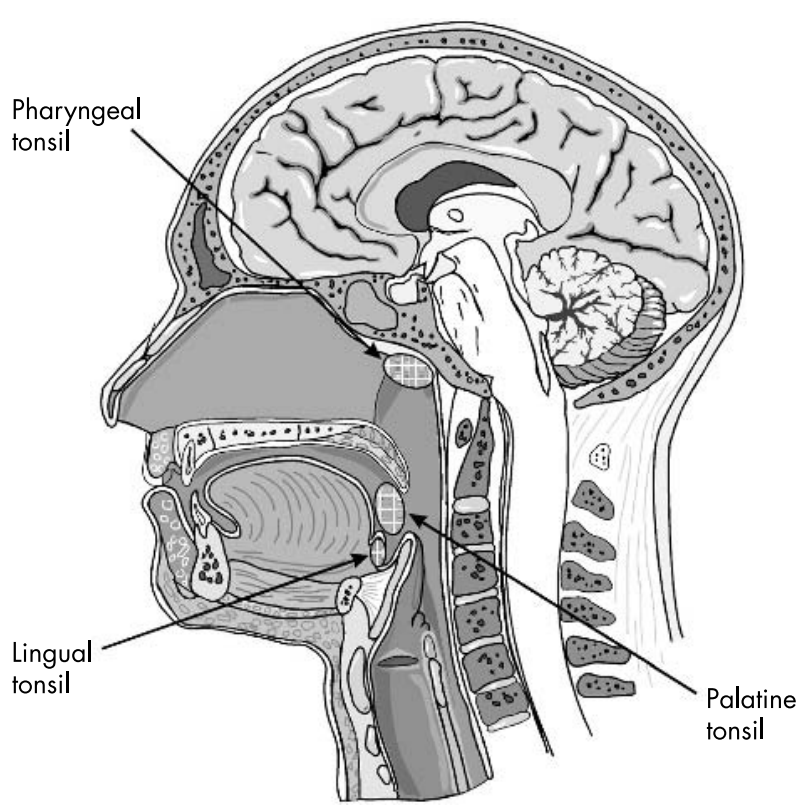

Figure 1 The localisation of the tonsils.

tonsillar pillars and the tonsillar fossa), soft palate, and pharyngeal folds. ${ }^{10}$

\section{CANCER OF THE UPPER AERODIGESTIVE TRACT}

The current literature uses this term to denote cancers of the oral cavity, pharynx (nasopharynx, oropharynx, and hypopharynx), larynx, and oesophagus. ${ }^{11}$ Often, this term also includes the trachea and bronchus. The interesting recent evidence linking HPV infections to tracheal and bronchial carcinomas was discussed in a recent review in this journal. ${ }^{12}$ In addition, the role of HPV in sinonasal carcinomas and those of the oesophagus has recently been reviewed in this journal. $^{13} 14$

\section{TONSILLAR CARCINOMA}

According to the old disease classification, cancer of the palatine tonsils was the most common tumour of the oropharynx. However, the incidence of tonsillar cancer has declined significantly in many countries because of the adoption of the new international classification of disease (ICD) since 1993. In the previous classification, palatine tonsillar carcinomas were included in category 146 (malignant neoplasms of the oropharynx), ${ }^{15}$ whereas the new ICD code is C09. ${ }^{16}$ The discrepancy in the incidence and prevalence figures is because, in addition to lesions of the tonsillae and fossa tonsillaris, the former 146 code included lesions of the arcus pharyngealis and glossopalate, valleculae, and epiglottidis. Code C09 of the ICD system includes lesions of the tonsillar fossa (C09.0), tonsillar pillar (C09.1), unspecified palatine tonsil, and overlapping lesions of the tonsil (C09.8), but excludes lingual tonsil (C02.4) and pharyngeal tonsil (C11.1).

The most common malignant tumour of the palatine tonsils is lymphoma, followed by squamous cell carcinoma (SCC). In some cancer registries, lymphomas are included in the incidence and prevalence figures of tonsillar cancer, whereas in others they are not, adding further confusion to the global cancer statistics. SCC of the palatine tonsils represents approximately $15-23 \%$ of all intraoral and oral pharyngeal squamous cell carcinomas in the USA. ${ }^{17}{ }^{18} \mathrm{~A}$ recent epidemiological survey indicated a fourfold increase of tonsillar SCC among white women in Connecticut between
1945 and 1994, although it remained relatively constant in white men. ${ }^{17}$ During 1973-1995, the incidence rates/1 million person years were considerably higher in blacks (31.6; 95\% confidence interval (CI), 29.0 to 34.4 in men; 9.6 ; 95\% CI, 8.3 to 10.9 in women) than in whites. No similar increase occurred for oral SCCs at non-tonsillar sites. ${ }^{17}$

In Finland, the age standardised incidence rate of cancer of the palatine tonsils doubled between 1956 and 2000 in both men and in women (fig 2). During 1996-2000, the incidence rates/1 million person years were 1.8 and 6.2 for women and men, respectively. The peak incidence for women is at the age of 45-69 years, and that for men at 45-59 years. ${ }^{19}$ Interestingly, no increase in the incidence rate of tonsillar SCCs is detected in the neighbouring country of Sweden. ${ }^{20}$

\section{Clinical features}

Clinical symptoms and signs of tonsillar cancer include pain (especially in the ear), difficulties in swallowing, tonsillar asymmetry, palpable firmness or visible lesions in the tonsil, neck mass, and unexplained weight loss. ${ }^{21}$ In the early stages the disease presents no symptoms. The overall five year survival rate is related to the stage of the disease, survival for stage I being close to $90 \%$, whereas patients with stage IV disease have a survival rate of less than $20 \% .^{22}$ Thus, the poor prognosis of the patients relates to the late detection of the disease. Surgery and/or radiotherapy are recommended for early disease (stages I/II) and a combination of radiotherapy and composite resection for stages III and IV.22 23

\section{Risk factors}

The most frequently reported risk factors for oral and pharyngeal carcinomas are smoking and alcohol. ${ }^{24}{ }^{25}$ These risk factors have not been specifically investigated in cancer of the palatine tonsils. Usually, patients with tonsillar cancer report a strong history of tobacco smoke and alcohol exposure. However, similar to oral cancer, increasing numbers of young individuals and elderly women without exposure to these chemical carcinogens have recently been reported to develop tonsillar SCC. ${ }^{176}$ Because the incidence of tonsillar SCC has increased, whereas the frequency of smokers has declined in the same period, additional risk factors probably exist for this malignancy. ${ }^{17} 2627$ Indeed, studies during the past decade suggest that a substantial proportion of tonsillar SCCs may be associated with

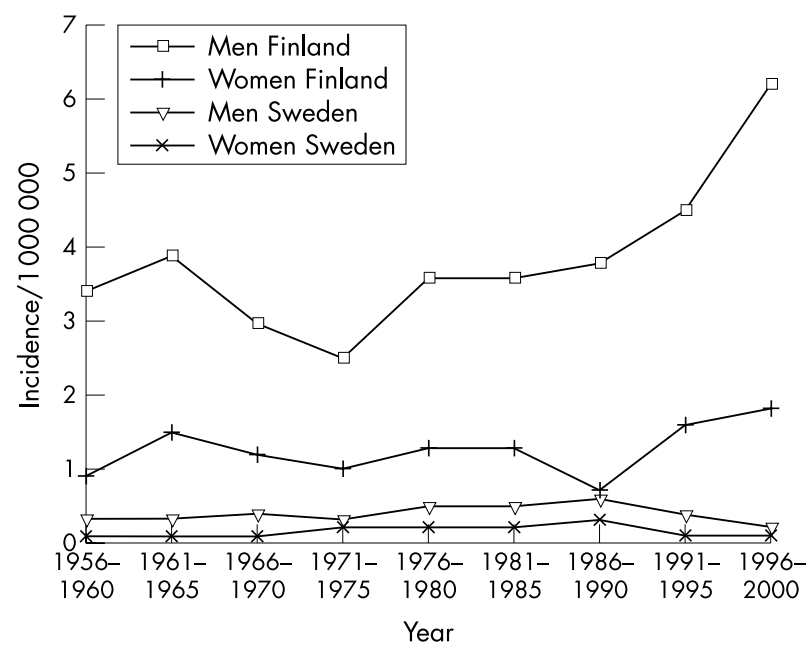

Figure 2 Incidence of tonsil cancer in Finland and Sweden 19562000 . 
oncogenic HPV infections. ${ }^{28}$ In the subsequent discussion, the word tonsils is used to refer to the palatine tonsils only, unless otherwise indicated.

\section{Tonsillar epithelium}

Tonsillar epithelium is of mesodermic and ectodermic origin, with the crypts populated by lymphocytes. The surface of both the palatine and lingual tonsils is covered by stratified squamous epithelium and a similar type of epithelium also lines the crypts. In pharyngeal tonsils, however, the epithelium is of the ciliated, pseudostratified columnar type, similar to the lining of the respiratory passages. ${ }^{1}$ In several studies discussed in detail below, it has been speculated that HPV associated tonsillar SCC originates from the epithelium of the crypts, whereas non-HPV related SCCs emerge from the tonsillar surface epithelium. ${ }^{17}{ }^{27}$ There are a few studies where in situ hybridisation has been used for HPV DNA detection in these lesions, but no attention has been paid to strict anatomical location of the infected epithelium or origin of the cancer. ${ }^{5930}$ Tyramide signal amplified in situ hybridisation is a very sensitive method that can detect even one single copy of HPV DNA. Using this method, HPV-16 DNA was detected in normal cryptal epithelium in a tonsillitis sample (fig 3). A carcinoma sample was also studied with the same method and nearly all the carcinoma cells labelled strongly with the HPV-16 DNA probe, indicating the presence of the episomal form of the virus.

\section{EVIDENCE FOR HPV INVOLVEMENT IN TONSILLAR CARCINOMA \\ Epidemiological studies}

Evidence suggesting an aetiological role for HPV in tonsillar carcinomas is derived from different approaches, including epidemiological and molecular studies.

It was recently shown that patients with HPV associated anogenital cancer had a 4.3 fold higher risk of tonsillar SCC (95\% CI, $2.7 \%$ to $6.7 \%$ ). ${ }^{26}$ The relative risk was significantly higher for tonsillar SCC than for other oral SCCs, supporting a causal role of HPV in the development of tonsillar SCC. The highest relative risk for tonsillar SCC was found in patients with anal SCC, which is common among male homosexuals $(2.6 \% ; 95 \%$ CI, $1.8 \%$ to $3.8 \%)$. However, the results of this study need to be interpreted with caution, because of the limited number of patients (only three human immunodeficiency virus infected men with anal and tonsillar

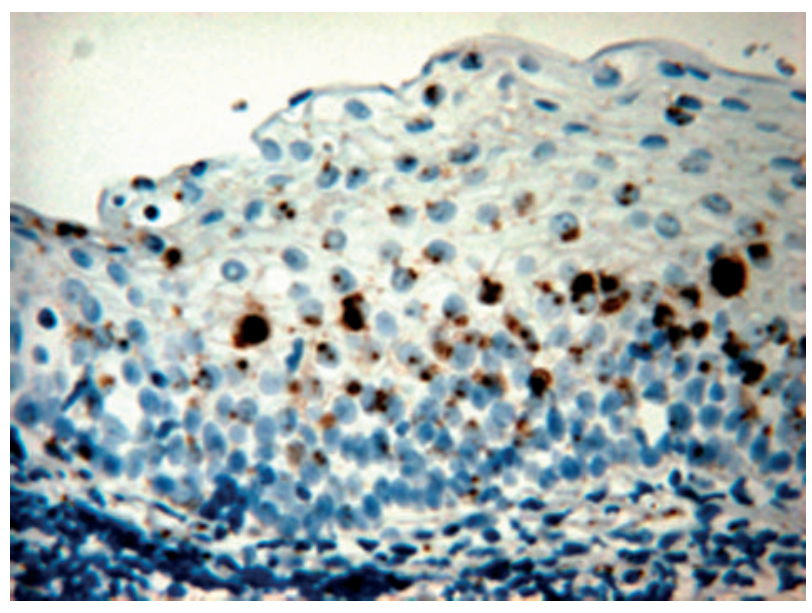

Figure 3 Tyramide amplified in situ hybridisation to detect human papillomavirus 16 DNA in the normal crypt epithelium of a tonsil during an episode of tonsillitis. Original magnification, $\times 250$. carcinoma). HPV unrelated cancers did not increase the risk of tonsillar carcinoma $(0.8 ; 95 \% \mathrm{CI}, 1.8 \%$ to $3.8 \%) .{ }^{26}$

Such an increased risk of tonsillar cancer was not associated with cervical HPV lesions in another study in Sweden. ${ }^{27}$ Different rates of tonsillectomy might partly explain the discrepancy between these two studies. More importantly, however, it was shown that husbands of patients with HPV associated cervical cancer had an increased risk of tonsillar cancer (standardised incidence rate, $>2.00$ ), which also suggests that HPV might be involved in tonsillar carcinogenesis. Such an association is further supported by the fact that HPV associated tonsillar carcinomas have been detected in transplant recipients, who have an increased risk of HPV infections. ${ }^{31} 32$

\section{Detection of HPV DNA}

Brandsma and Abramson were the first to report the presence of HPV-16 DNA in two of seven tonsillar SCCs using Southern blot hybridisation in $1989 . .^{33}$ Since that preliminary report, large numbers of studies have reported on the detection of HPV DNA in tonsillar SCCs (summarised in table 1). However, practically no data are available on the detection of HPV DNA in the tonsillar tissues of Waldeyer's ring other than the palatine tonsils.

One year after the original report, Ishibashi and co-workers described an additional tonsillar SCC infected with an episomal form of HPV-16 DNA. ${ }^{34}$ The same HPV type was also detected in two lymph node metastases, suggesting a direct role for HPV infection in the development of SCC. The two largest series of tonsillar carcinomas analysed for HPV so far have been reported by Mellin and co-workers (2002). ${ }^{346}$ They analysed a total of 84 tonsillar carcinomas, 39 of which contained HPV DNA. ${ }^{3}{ }^{4}$

"It was shown that husbands of patients with human papillomavirus associated cervical cancer had an increased risk of tonsillar cancer"

At the time of writing (February 2003), the world literature comprises a total of 432 tonsillar SCCs analysed for the presence of HPV DNA by a variety of detection techniques (table 1). HPV DNA has been detected in 51\% (221 of 432) of these lesions. Most of these studies are not focused solely on tonsillar SCCs, but on head and neck tumours in general. Thus, the cases of tonsillar SCCs listed in table 1 have been collected from the studies reporting oral, aerodigestive tract, or head and neck cancers.

The most prevalent HPV type detected in tonsillar SCCs seems to be HPV-16, being identified in $84 \%$ of the $216 \mathrm{HPV}$ DNA positive tumours. In addition, HPV-16 was present as double infections (16/18 and $16 / 33)$ in $3 \%$ and $1.4 \%$ of the HPV DNA positive samples, respectively. HPV-33 has been found in only $4.6 \%$ of HPV positive tonsillar carcinomas. Interestingly, DNA from the low risk HPV types 6/1 1 has also been detected in 3\% of HPV positive tonsillar carcinomas. In addition to the HPV types listed above (and some unidentified HPV types), the following HPV types have been detected in occasional tonsillar carcinomas: HPV types 5, 12, 31, 35, and 59 (table 1).

\section{Physical state of HPV in tonsillar carcinomas}

The physical state of HPV in tonsillar carcinomas has not been analysed systematically and, in fact, such data are available in a few studies only. In 1991, Bercovich and coworkers reported both integrated and episomal forms of HPV-6a in tonsillar SCCs. ${ }^{35}$ HPV-6 is included among the low risk mucosal HPV types that are rarely found in malignant tumours. ${ }^{28}{ }^{42}$ However, HPV-6 or HPV-11 DNA has occasionally been found in vulvar carcinomas, cervical carcinomas, 


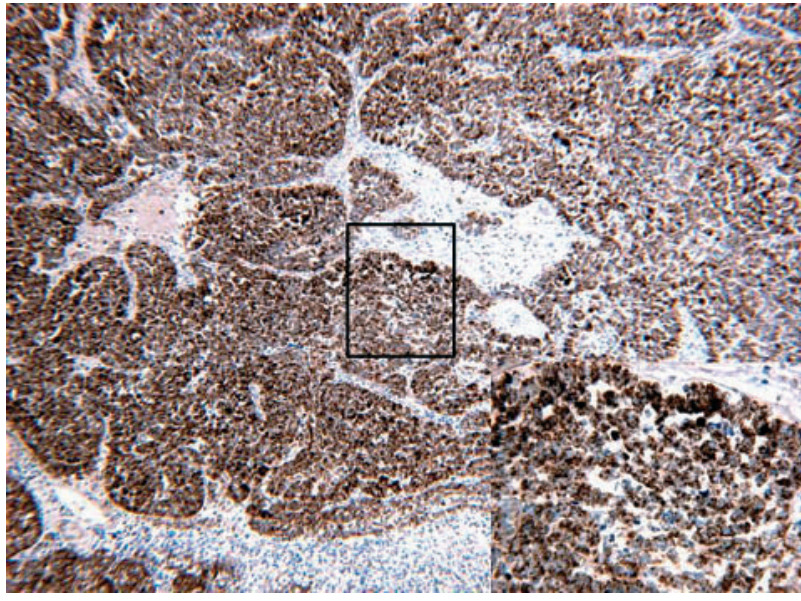

Figure 4 Tyramide amplified in situ hybridisation in the detection of human papillomavirus 16 DNA in a tonsillar squamous cell carcinoma. Original magnification, $\times 40$. The insert shows a high power view

(original magnification, $\times 250$ ) of the area marked with a rectangle.

laryngeal papillomas on malignant transformation, and in most cases of Buschke-Löwenstein tumours (giant condylomas). ${ }^{28} 42$ Subsequently, the same authors reported that in this particular tonsillar SCC, HPV-6a was integrated into chromosome 10q24. ${ }^{53}$ At the HPV-6a integration site, there were also breakpoints affecting protooncogenes Hoxll and Lyt 10, and genes related to cell division. ${ }^{53}$ There is a fragile site in the same region and, interestingly, integration of HPV-18 into the chromosome at 10q24 has also been reported..$^{53}$

More recently, Mellin and colleagues provided evidence that all HPVs detected in 11 of the 22 tonsillar carcinoma samples analysed were in the episomal form. ${ }^{3}$ The physical state was analysed by a very sensitive restriction enzyme digestion, ligation, and inverse PCR method. Previously, Snijders et al (1992) had described two HPV-16 positive tonsillar carcinomas, where HPV-16 was episomal. They also found two HPV-33 positive carcinomas, where HPV was either integrated or in both the episomal and integrated form. ${ }^{54}{ }^{55}$ It is currently unknown why HPV is mostly in the episomal form in tonsillar carcinomas. One possible explanation could be genetic alterations of the long control region of extrachromosomal HPV, leading to dysregulation of the viral oncogenes. The sequence analyses of episomal HPV-16 in cervical cancers has revealed sequence variation in YYl binding sites, leading to increased activity of the viral oncogene promoter. ${ }^{56}{ }^{57}$ Similarly, Mellin et al (2002) reported episomal but deleted HPV-16 in three tonsillar carcinomas. ${ }^{3}$ In all three cases, HPV-16 was disrupted at the end of the E1 open reading frame (ORF), and E2 was missing. In two carcinomas, the deletion of HPV-16 continued into the long control region, whereas in the third case deletion continued into the E6 ORF. ${ }^{3}$ The biological implications of the deletions remained obscure. As described below, it seems that the pathogenesis of HPV induced tonsillar carcinoma is different to that of cervical carcinoma, where HPV is mostly in the integrated form.

"It is currently unknown why human papillomavirus is mostly in the episomal form in tonsillar carcinomas"

We recently described an HPV-33 positive cell line established from a vaginal mild dysplasia lesion, where HPV was mostly detected episomally at early passages. ${ }^{58}$ However, at passages 18-20 onward, only the integrated form was detected. ${ }^{58}$ After identifying the exact integration site of HPV-33 at chromosome 5pl4, we were able to trace the

Table 1 Detection of HPV DNA in tonsillar carcinomas

\begin{tabular}{|c|c|c|c|c|c|c|c|c|c|c|}
\hline \multirow[b]{2}{*}{ Technique } & \multirow[b]{2}{*}{ No of positive cases/total } & \multicolumn{9}{|c|}{ HPV types } \\
\hline & & $6 / 11$ & 16 & 18 & $16 / 18$ & $16 / 33$ & 31 & 33 & $\mathbf{x}$ & First author (year) \\
\hline SB & $2 / 7$ & 1 & 1 & & & & & & & Brandsma $(1989)^{33}$ \\
\hline SB & $1 / 1$ & & $1^{*}$ & & & & & & & Ishibashi $(1990)^{34}$ \\
\hline ISH & $6 / 28$ & & 6 & & & & & & & Niedobitek $(1990)^{29}$ \\
\hline SB & $1 /$ & 1 & & & & & & & & Bercovitch $(1991)^{35}$ \\
\hline ISH & $5 /$ & & & & 5 & & & & & Arndt $(1992)^{30}$ \\
\hline PCR & $10 / 10$ & & 4 & & & 1 & & 3 & 2 & Snijders $(1992)^{5}$ \\
\hline PCR & $12 / 14$ & & 7 & & & 1 & & 2 & 2 & Snijders $(1994)^{36}$ \\
\hline PCR & $2 / 3$ & & & & & & & & & Brachman $(1992)^{37}$ \\
\hline PCR, SB, & $3 / 6$ & & 3 & & & & & & & Watanabe $(1993)^{38}$ \\
\hline $\begin{array}{l}\text { Virapap } \\
\text { PCR SB }\end{array}$ & $1 / 4$ & & 1 & & & & & & & Oaura $(1993)^{39}$ \\
\hline PCR & $\begin{array}{l}1 / 4 \\
2 / 4\end{array}$ & & 2 & & & & & & & Lewensohn-Fuchs $(1994)^{40}$ \\
\hline PCR & $3 / 7$ & & & & & & & & ND & Brandwein $(1994)^{41}$ \\
\hline PCR, SB & $9 / 15$ & & 8 & & & & & & 1 & $\operatorname{Paz}(1997)^{\circ}$ \\
\hline PCR, SB & $1 / 1$ & & 1 & & & & & & & Turazza $(1997)^{42}$ \\
\hline PCR, SB & $11 / 21$ & & 8 & & & & & 1 & 2 & Andl $(1998)^{43}$ \\
\hline PCR, SB & $19 / 44$ & 3 & 40 & & & & & & & Schwarz $(1998)^{44}$ \\
\hline PCR & $14 / 22$ & & 11 & & & & & 1 & 2 & Wilczyski $(1998)^{45}$ \\
\hline PCR & $2 / 2$ & $1^{*}$ & & & $1^{*}$ & & & & & Badaracco $(2000)^{46}$ \\
\hline PCR & $6 / 13$ & & & & & & $6 \dagger$ & & & Lopez-Lizarraga $(2000)^{47}$ \\
\hline SB & $1 / 1$ & & 1 & & & & & & & Ishiii $(2000)^{48^{\circ}}$ \\
\hline PCR & $2 / 4$ & 1 & & & 1 & & & & & Badaracco $(2000)^{49}$ \\
\hline PCR & $32 / 52$ & & & & & & & & & Gillison $^{* *}(2000)^{7}$ \\
\hline PCR & $26 / 60$ & & 26 & & & 1 & & & & Mellin $(2000)^{6}$ \\
\hline PCR & $12 / 22$ & & 11 & & & & & 1 & & Mellin $(2002)^{3}$ \\
\hline PCR & $14 / 24$ & & $12 \ddagger$ & & & & & 1 & 1 & Klussman $(2001)^{50}$ \\
\hline $\mathrm{PCR}, \mathrm{SB}$ & $24 / 52$ & & $21 \oplus$ & & & & & & $3 \S$ & $\begin{array}{l}\text { Strome }(2002)^{51} \\
\text { Ringström }(2002)^{52}\end{array}$ \\
\hline Total (\%) & $221 / 432(51)$ & $7(3)$ & $186(84)$ & & $7(3)$ & $3(1.4)$ & $6(2.8)$ & $9(4.6)$ & $13(6)$ & \\
\hline
\end{tabular}

*Triple infection with HPV types 6, 16, and 18; †one infection with several HPV types 6, 18, 31, and 35; ‡double infections with HPV types 5/16, ADX1/16; §HPV-12, HPV-59; -one unidentified and HPV-59; **includes also tumours of the lingual tonsils.

HPV, human papillomavirus; ISH, in situ hybridisation; PCR, polymerase chain reaction; SB, Southern blotting. 
Table 2 Detection of HPV in normal tonsillar mucosa or benign lesions

\begin{tabular}{|c|c|c|c|c|c|c|c|c|}
\hline Type of lesion & Technique & No of cases & $6 / 11$ & 16 & 18 & 31 & 33 & First author (date) \\
\hline Tonsillitis & SB & $0 / 20$ & & & & & & Brandsma $(1989)^{33}$ \\
\hline $\begin{array}{l}\text { Chronic inflammatory } \\
\text { disease }\end{array}$ & $\mathrm{ISH}$ & $0 / 30$ & & & & & & Niedobitek $(1990)^{29}$ \\
\hline Tonsillitis & PCR & $0 / 7$ & & & & & & Snijders $(1992)^{5}$ \\
\hline $\begin{array}{l}\text { Normal posterior } \\
\text { tonsillar pilar }\end{array}$ & PCR, SB & $1 / 3$ & 1 & & & & & Smith $(1993)^{60}$ \\
\hline Chronic tonsillitis & PCR, SB & $4 / 28$ & & 4 & & & & Watanabe $(1993)^{38}$ \\
\hline $\begin{array}{l}\text { Adenoid hyperplasia } \\
\text { and chronic tonsillitis }\end{array}$ & PCR, SB & $0 / 8,5 / 38$ & & 5 & & & & Fukushima $(1994)^{61}$ \\
\hline Condyloma & SB & $1 / 1$ & 1 & & & & & Tominaga $(1996)^{62}$ \\
\hline Normal mucosa & SB & $3 / 3$ & 3 & & & & & Tominaga $(1996)^{62}$ \\
\hline Chronic tonsillitis & PCR & $0 / 14$ & & & & & & Klussmann $(2001)^{50}$ \\
\hline Tonsillar hyperplasia & PCR, SB & $3 / 48$ & & 3 & & & & Strome $(2002)^{51}$ \\
\hline
\end{tabular}

In total, 17/200 (8.5\%) samples were HPV positive.

$\mathrm{HPV}$, human papillomavirus; ISH, in situ hybridisation; PCR, polymerase chain reaction; SB, Southern blotting.

presence of the integrated form of HPV-33 at early passages and even in the original biopsy. However, the copy numbers of the integrated form of HPV-33 were very low. ${ }^{58}$ In line with these results, we also found that most premalignant HPV-16 positive lesions (cervical intraepithelial neoplasia I-III) contained the integrated form of HPV-16, mixed with episomal forms, by using a new real time polymerase chain reaction method..$^{59}$ Our studies with genital lesions suggest that integration is an early event in HPV induced carcinogenesis.

\section{Viral load in tonsillar carcinoma}

Mellin and co-workers recently showed that there is a wide variation in copy numbers of HPV DNA in tonsillar carcinomas. ${ }^{3}$ Most tonsillar carcinomas contained between 10 and a few hundred copies for each copy of $\beta$ actin DNA. ${ }^{3}$ Notably, six patients with tumours containing $>190$ copies/ $\beta$ actin showed a significantly better clinical outcome, as measured by recurrence free three year survival after diagnosis $(p=0.026)$, and better overall survival rates $(\mathrm{p}=0.039)$, than did the five patients with tumours containing $<190$ HPV copies/ $\beta$ actin. ${ }^{3}$ They also showed that overall survival was better for patients with HPV DNA positive tumours than for those with HPV negative cancers. Similar results have also been shown by others. ${ }^{50}$

\section{Expression of viral oncogenes in tonsillar carcinoma} It should be emphasised that the detection of viral DNA per se does not confirm that the virus has a causal association with malignant transformation. However, based on the still limited material, it now seems that HPV-16 E6 and E7 are actively transcribed in most of the tonsillar carcinomas that have been analysed. ${ }^{8} 45455$ Snijders and co-workers (1992) showed that independent of the physical state of the virus, all tumours expressed E7 encoding HPV-33 E6*I mRNA. They also suggested that the transcription of HPV-16 E6/E7 mRNA in tonsillar carcinomas is not necessarily dependent on viral DNA integration..$^{55}$

\section{HPV DETECTION IN NORMAL TONSILS OR TONSILLITIS}

Normal tonsillar tissues have been assessed in only a few studies. By the end of the year 2002, only 200 normal tonsillar samples and/or biopsy samples from tonsillitis were analysed for the presence of HPV DNA. In total, 8.5\% (17 of 200; table 2) of the samples contained HPV DNA, either type 16 (12 samples) or 6/11 (five samples). As in other anatomical sites, the positivity rate of HPV is expected to increase when more samples of normal tissues are analysed.

\section{CONCLUSIONS}

The HPV detection rate of $51 \%$ is among the highest in any extragenital human malignancy. ${ }^{28}$ In fact, it is more than twice as high as that established in the current literature for other upper aerodigestive tract carcinomas, such as sinonasal, bronchial, and oesophageal carcinomas. ${ }^{11-13}$

In several other respects, tonsillar carcinomas have special features that mark them out among the known and emerging HPV lesions. First, tonsillar carcinomas are mostly infected with HPV type 16; second, the virus is predominately in episomal form; and third the virus is transcribed. How the virus can remain in carcinoma tissues as episomes with relatively high copy numbers is not yet known.

"The human papillomavirus detection rate of $51 \%$ is among the highest in any extragenital human malignancy"

\section{Take home messages}

- Tonsillar carcinoma is the most prevalent oropharyngeal carcinoma

- Cigarette smoking and alcohol are the primary risk factors traditionally associated with the development of this malignancy

- The association of human papilloavirus (HPV) infection with tonsillar carcinoma has been suggested by the following observations: HPV DNA has been detected in around $50 \%$ of tonsillar carcinomas; HPV-16 is the predominant virus type in tonsillar carcinomas; HPV16 is present in episomal form in most tonsillar carcinomas; HPV is transcribed in tonsillar carcinomas and HPV DNA is detectable in carcinoma cells by in situ hybridisation; patients with anogenital cancer might have an increased risk for tonsillar carcinoma; HPV DNA has also been detected in lymph node metastases

- Patients with HPV-16 positive tumours seem to have a better survival than HPV negative patients, thus presenting a distinct group among patients with tonsillar carcinoma

- The new international disease classification has led to a decreased incidence of palatine tonsillar carcinomas, because the posterior part of the tongue is no longer included in the CO9 code 
The mode of entry of HPV into tonsillar tissue is not known. Tonsillar crypt epithelium is known to capture and process antigens, which might facilitate viral access to the basal cells. The possibility of persistence of the virus in the crypt epithelium and even in lymphoid tissue cannot be totally excluded. If this is true, tonsillar tissue could represent a reservoir of HPV in the upper aerodigestive tract. This view is partly supported by the fact that when oral samples are collected by oral rinse, the detection rate of HPV is much higher that that with swabs. Finally, the persistence of HPV in tonsillar tissue might be of importance in the immune response to $\mathrm{HPV}$.

\section{REFERENCES}

1 Geneser F. Textbook of histology. Copenhagen: Munsgaard, 1986.

2 Brook I. The clinical microbiology of Waldeyer's ring. Otolaryngol Clin North Am 1987;20:259-72.

3 Mellin H, Dahlgren L, Munck-Wikland E, et al. Human papillomavirus type 16 is episomal and a high viral load may be correlated to better prognosis in tonsillar cancer. Int J Cancer 2002;102:152-8.

4 Mellin H. Human papillomavirus in tonsillar carcinoma. Stockholm, Sweden: Karolinska University Press, 2002

5 Snijders PJF, Cromme FV, van den Brule AJC, et al. Prevalence and expression of human papillomavirus in tonsillar carcinomas, indicating a possible viral etiology. Int J Cancer 1992;52:845-50.

6 Mellin H, Friesland S, Lewensohn R, et al. Human papillomavirus (HPV) DNA in tonsillar cancer: clinical correlates, risk of relapse, and survival. Int $J$ Cancer 2000;89:300-4

7 Gillison ML, Koch WM, Capone RB, et al. Evidence for a causal association between human papillomavirus and a subset of head and neck cancers. J Natl Cancer Inst 2000;92:709-20.

8 Mork J, Lie AK, Glattre E, et al. Human papillomavirus infection as a risk factor for squamous-cell carcinoma of the head and neck. N Engl J Med 2001:344:1125-31.

9 Paz IB, Cook N, Odom-Maryon T, et al. Human papillomavirus (HPV) in head and neck cancer. An association of HPV 16 with squamous cell carcinoma of Waldeyer's tonsillar ring. Cancer 1997;79:595-604.

10 Barnes L, Johnson JT. Pathologic and clinical considerations in the evaluation of major head and neck specimens resected for cancer. Part I. J Pathol Annu 1986;21:173-250.

11 Franceschi S, Munoz N, Bosch X, et al. Human papillomavirus and cancer of the upper aerodigestive tract: a review of epidemiological and experimental evidence. Cancer Epidemiol Biomarkers Prev 1996:5:567-75.

12 Syriänen KJ. HPV infections in lung cancer. J Clin Pathol 2002;55:885-91

13 Syrïanen KJ. HPV infections in benign and malignant sinonasal lesions. J Clin Pathol 2003;56:174-81.

14 Syriänen KJ. HPV infections and oesophageal cancer. J Clin Pathol 2002;55:721-8.

15 Manual of the international statistical classification of diseases, injuries, and causes of death. Geneva: World Health Organisation, 1979.

16 International statistical classification of diseases and related health problems, 10th revision. Geneva: World Health Organisation, 1993.

17 Frisch M, Hjalgrim H, Bonnerup Jaeger A, et al. Changing patterns of tonsillar squamous cell carcinoma in the United States. Cancer Causes Control 2000;1 1:489-95

18 Frisch M, Goodman MT. Human papillomavirus-associated carcinomas in Hawaii and the mainland. Cancer 2000;88:1464-9.

19 Finnish Cancer Registry (www.cancerregistry.fi).

20 Swedish Cancer Registry (www.sos.se/epc).

21 Beaty MM, Funk GF, Karnell LH, et al. Risk factors for malignancy in adult tonsils. Head Neck 1998;20:399-403.

22 Givens CD Jr, Johns ME, Cantrell RW. Carcinoma of the tonsil. Analysis of 162 cases. Arch Otolaryngol 1981;107:730-4.

23 Hicks WL Jr, Kuriakose MA, Loree TR, et al. Surgery versus radiation therapy as single-modality treatment of tonsillar fossa carcinoma: the Roswell Park Cancer Institute experience (1971-1991). Laryngoscope 1998;108:1014-19.

24 Bagnardi V, Blangiardo M, La Vecchia C, et al. A meta-analysis of alcohol drinking and cancer risk. Br J Cancer $2001 ; 85: 1700-5$.

25 Lewin $\mathrm{F}$, Norell SE, Johansson $\mathrm{H}$, et al. Smoking tobacco, oral snuff, and alcohol in the etiology of squamous cell carcinoma of the head and neck. A population-based case-referent study in Sweden. Cancer 1998:82:1367-75.

26 Frisch M, Biggar RJ. Aetiological parallel between tonsillar and anogenital squamous-cell carcinomas. Lancet 1999;354:1442-3.

27 Hemminki K, Dong C, Frish M. Tonsillar and other upper aerodigestive tract cancers among cervical cancer patients and their husbands. Eur J Cancer Prev 2000;9:433-7.

28 Syriänen K, Syriänen S. Papillomavirus infections in human pathology. London: Wiley, 2000

29 Niedobitek G, Pitteroff S, Herbst $H$, et al. Detection of human papillomavirus type 16 DNA in carcinomas of the palatine tonsil. J Clin Pathol 1990;43:918-21.
30 Arndt O, Zeise K, Baver I, et al. Humane Papillomviren (HPV) vom Typ 6/11 und 16/18 in Plattenepithelkarzinomen des oberen Atmungs-und Verdauungstraktes. Eine In-situ-Hybridisierungsstudie. Laryngorhinootologie 1992;71:500-4.

31 Demetrick D, Inoue $M$, Lester W, et al. Human papillomavirus type 16 associated with oral squamous cell carcinoma in a cardiac transplant recipient. Cancer 1990;66:1726-31.

32 Swoboda A, Fabrizii V. Tonsillar carcinoma in a renal graft recipient treated with cyclosporine. Clin Nephrol 1993:39:272-4.

33 Brandsma JL, Abramson AL. Association of papillomavirus with cancers of the head and neck. Arch Otolaryngol Head Neck Surg 1989; 115:621-5

34 Ishibashi T, Matsushima S, Tsunokawa Y, et al. Human papillomavirus DNA in squamous cell carcinoma of the upper aerodigestive tract. Arch Otolaryngol Head Neck Surg 1990;1 16:294-8.

35 Bercovich JA, Centeno CR, Aguilar OG, et al. Presence and integration of human papillomavirus type 6 in a tonsillar carcinoma. J Gen Virol 1991;72:2569-72.

36 Snijders PJF, Steenbergen RDM, Top B, et al. Analysis of p53 status in tonsillar carcinomas associated with human papillomavirus. J Gen Virol 1994:75:2769-75.

37 Brachman DG, Graves D, Vokes E, et al. Occurrence of p53 gene deletions and human papilloma virus infection in human head and neck cancer. Cancer Res 1992;52:4832-6

38 Watanabe S, Ogura H, Fukushima K, et al. Comparison of Virapap filter hybridization with polymerase chain reaction and Southern blot hybridization methods for detection of human papillomavirus in tonsillar and pharyngeal cancers. Eur Arch Otorhinolaryngol 1993;250:1 15-19.

39 Ogura H, Watanabe S, Fukushima K, et al. Human papillomavirus DNA in squamous cell carcinomas of the respiratory and upper digestive tracts. Jpn J Clin Oncol 1993;23:221-5.

40 Lewensohn-Fuchs I, Munck-Wikland E, Berke Z, et al. Involvement of aberrant p53 expression and human papillomavirus in carcinoma of the head, neck and esophagus. Anticancer Res 1994;14:1281-5.

41 Brandwein M, Zeitlin J, Nuovo GJ, et al. HPV detection using "hot start" polymerase chain reaction in patients with oral cancer: a clinicopathological study of 64 patients. Mod Pathol 1994;7:720-7.

42 Turazza E, Lapeña A, Sprovieri O, et al. Low-risk human papillomavirus types 6 and 11 associated with carcinomas of the genital and upper aero-digestive tract. Acta Ostet Gynecol 1997;76:271-6.

43 Andl T, Kahn T, Pfuhl A, et al. Etiological involvement of oncogenic human papillomavirus in tonsillar squamous cell carcinomas lacking retinoblastoma cell cycle control. Cancer Res 1998;58:5-13.

44 Schwarz SM, Daling JR, Doody DR, et al. Oral cancer risk in relation to sexual history and evidence of human papillomavirus infection. J Natl Cancer Inst 1998;90:1626-36.

45 Wilczynski SP, Lin BT, Xie Y, et al. Detection of human papillomavirus DNA and oncoprotein overexpression are associated with distinct morphological patterns of tonsillar squamous cell carcinoma. Am J Pathol 1998; 152:145-56.

46 Badaracco G, Venuti A, Morello R, et al. Human papillomavirus in head and neck carcinomas; prevalence, physical status and relationship with clinical/ pathological parameters. Anticancer Res 2000;20:1301-6.

47 Lopez-Lizarraga E, Sanchez-Corona J, Montoya-Fuentes $\mathrm{H}$, et al. Human papillomavirus in tonsillar and nasopharyngeal carcinoma: isolation of HPV subtype 31. Ear Nose Throat J 2000;79:942-4.

48 Ishiji T, Kawase M, Honda M, et al. Distinctive distribution of human papillomavirus type 16 and type 20 DNA in the tonsillar and the skin carcinomas of a patient with epidermodysplasia verruciformis. $\mathrm{Br} J$ Dermatol 2000; 143:1005-10.

49 Badaracco G, Venut A, Bartolazzi A, et al. Overexpression of p53 and bcl-2 proteins and the presence of HPV infection are independent events in head and neck cancer. J Oral Pathol Med 2000;29:173-9.

50 Klussman JP, Weissenborn SJ, Wieland U, et al. Prevalence, distribution, and viral load of human papillomavirus 16 DNA in tonsillar carcinomas. Cancer $2001 ; 92: 2875-84$.

51 Strome SE, Savva A, Brissett AE, et al. Squamous cell carcinoma of the tonsils: a molecular analysis of HPV associations. Clin Cancer Res 2002;8: 1093-100.

52 Ringström E, Peters E, Hasegawa, et al. Human papillomavirus type 16 and squamous cell carcinoma of the head and neck. Clin Cancer Res 2002:8:3187-92.

53 Kahn T, Turazza E, Ojeda R, et al. Integration of human papillomavirus type 6a DNA in a tonsillar carcinoma: chromosomal localization and nucleotide sequence of the genomic target region. Cancer Res 1994:54:1305-12.

54 Snijders PJF, Meijer CJL, van den Brule AJC, et al. Human papillomavirus (HPV) type 16 and 33 E6/E7 region transcripts in tonsillar carcinomas can originate from integrated and episomal HPV DNA. J Gen Virol 1992;73:2059-66

55 Snijders PJF, van den Brule AJC, Schrijnemakers HFJ, et al. Human papillomavirus type 33 in a tonsillar carcinoma generates its putative E7 mRNA via two E6 transcript species which are terminated at different early region poly(A) sites. J Virol 1992;66:3172-8.

56 Dong XP, Stubenrauch F, Beyer-Flinker E, et al. Prevalence of deletions of YY1-binding sites in episomal HPV 16 DNA from cervical cancers. Int $J$ Cancer 1994;58:803-8.

57 Watts KJ, Thompson $\mathrm{CH}$, Cossart YE. Variable oncogene promoter activity of human papillomavirus type cervical cancer isolates from Australia. J Clin Microbiol 2001;39:2009-14. 
58 Peitsaro P, Hietanen S, Johansson B, et al. Single copy heterozygote integration of HPV 33 in chromosomal band 5 p1 4 gives rise to an epithelial cell clone with selective growth advantage. Carcinogenesis 2002;6:1057-64.

59 Peitsaro $\mathbf{P}$, Johansson B, Syrjanen $\mathrm{S}$. Integrated human papillomavirus type 16 is frequently found in cervical cancer precursors as demonstrated by a novel quantitative real-time PCR technique. J Clin Microbiol 2002;40:886-91.

60 Smith EM, Pignatari SSN, Gray SD, et al. Human papillomavirus infection in papillomas and nondiseased respiratory sites of patients with recurrent respiratory papillomatosis using the polymerase chain reaction. Arch Otolaryngol Head Neck Surg 1993;1 19:554-7.

61 Fukushima K, Ogura H, Watanabe S, et al. Human papillomavirus type 16 DNA detected by the polymerase chain reaction in non-cancer tissues of the head and neck. Eur Arch Otorhinolaryngol 1994;251:109-12.

62 Tominaga S, Fukushima O, Ohama T, et al. Presence of human papillomavirus type $6 f$ in tonsillar condyloma acumicatum and clinically normal tonsillar mucosa. Jpn J Clin Oncol 1996;26:393-7. 